\title{
An Experimental Insight into the ZnO Thin Films Properties Prepared by Dip Coating Technique
}

\author{
M. Benhaliliba ${ }^{1}$, Y.S. Ocak ${ }^{2}$ \\ 1 Material Technology Department, Physics Faculty, USTOMB University, BP1505 Oran, Algeria \\ ${ }_{2}^{2}$ Dicle University, Education Faculty, Science Department, 21280 Diyarbakir, Turkey
}

(Received 04 August 2015; revised manuscript received 02 March 2016; published online15 March 2016)

\begin{abstract}
The physical properties of the pure and metal doped $\mathrm{ZnO}$ films are investigated using a low cost dip coating technique. The films have grown slowly onto a glass substrate at room temperature. Based on Xray pattern parameters are extracted such as grain size, lattice parameters. Optical measurements within the UV-Vis band give us the transmittance of films (> $80 \%)$ and optical band gap. Using the Hall Effect measurement (HMS) in room temperature, we determine the bulk density of charge carriers, mobility and their electrical resistivity.
\end{abstract}

Keywords: Zinc oxide, Film synthesis, Metal doping, Dip coating, Structural parameters, Transmittance, Optical band gap, Resistivity.

DOI: 10.21272/jnep.8(1).01040

PACS numbers: 77.84.Bw, 68.47.Gh

\section{INTRODUCTION}

$\mathrm{ZnO}$ is the multifunctional material which attracted many researchers during the last decades. As film, it is produced by many processes like spray pyrolysis, sputtering, spin and dip coating [1-4]. We find zinc oxide in many applications such as ultraviolet light emitters and thin film transistors [5-6]. In order to study the influence of molarity on the $\mathrm{ZnO}$ layer properties, the films are prepared by low cost dip coating process. We select the zinc molarity within the $0.2-0.5 \mathrm{~mol} /$ litre range. Furthermore, at kept zinc acetate molarity of $0.4 \mathrm{~mol} / \mathrm{litre}$, the effect of metal doping at various rates on $\mathrm{ZnO}$ film properties is investigated.

\section{PREPARATION OF LAYERS}

For the dip-coating route, the substrate is pulled vertically from the coating bath at a constant speed $\mathrm{V}$ as sketched in Fig. 1. The entrained liquid by the moving substrate splits into two at the free surface (point $S$ ) in a viscous boundary layer, returning the outer layer to the bath. When the mounting moving flux is balanced above the stagnation point $\mathrm{S}$ due to evaporation of the solvents, a continuing and position-stable film is formed with respect to the coating bath surface. Inside the drying process, the colloids are gradually concentrated by evaporation, leading to aggregation, gelation, and final drying to synthesize a type of a dry gel or xerogel film. If the substrates' speed $(V)$ and liquid viscosity $(\eta)$ are lower, e.g. in the case of the solgel coating, the thickness (it) of the wet film is then expressed as [7]:

$$
t=\left(\frac{0.94(\eta V)^{0.67}}{\gamma_{s}^{0.17}(\rho g)^{0.5}}\right),
$$

where $\gamma_{s}$ is the liquid-vapour surface tension, $\rho$ is the liquid density and $g$ is the acceleration of gravity. For a fixed volume of $20 \mathrm{ml}$ of ethanol and different zinc acetate masses mentioned between brackets, the following molarities are obtained $0.2(0.87 \mathrm{~g}), 0.3(1.32 \mathrm{~g}), 0.4$
(1.76 g) and 0.5 (2.19 g). After a stirring at $80{ }^{\circ} \mathrm{C}$, the prepared solutions are clear and homogenous and seem to oil which reveals a viscous bath. As soon as the bath is ready, the glass substrates are slowly dipped into the solution during $1 \mathrm{~min}$ and then removed and dried at $120{ }^{\circ} \mathrm{C}$ on the hotplate. The process of dip is repeated 10 times and an annealing procedure of samples is then achieved at $400{ }^{\circ} \mathrm{C}$ for 5 hours. For doping the $\mathrm{SnCl}_{2}$, $2 \mathrm{H}_{2} \mathrm{O}, \mathrm{Fe}_{2} \mathrm{Cl}_{3}, 6 \mathrm{H}_{2} \mathrm{O}, \mathrm{Al}_{3} \mathrm{NO}_{3}, 9 \mathrm{H}_{2} \mathrm{O}$ and anhydrous $\mathrm{Cu}$ acetate precursors are used.

\section{RESULTS AND DISCUSSIONS}

The samples prepared by dip coating process are classified in three sets. The first one is composed of pure zinc oxide layers at different zinc amounts (0.2$0.5 \mathrm{~mol} / \mathrm{l}$ ) while the second set is formed by $2-20 \% \mathrm{Sn}$ doped $\mathrm{ZnO}$ layers. $2-3 \% \mathrm{Fe}, 12 \% \mathrm{Al}$ and $10 \% \mathrm{Cu}$ doped $\mathrm{ZnO}$ form the third set.

\subsection{Structural Parameters}

Figure 2 shows the XRD peaks of the dip coated $\mathrm{ZnO}$ at several zinc amounts in the starting solution Fig. 2I, $\mathrm{Sn}, \mathrm{Al}$ and $\mathrm{Cu}$-doped $\mathrm{ZnO}$ layers Fig. 2II, Fig. 2III respectively. As gathered in Table 1, the main orientations exhibited by $\mathrm{ZnO}$ layers (1 ${ }^{\text {st }}$ set) are (002) and (101) which are located within $34.4^{\circ}-34.5^{\circ}$ and $34.5^{\circ}-35.7^{\circ}$ angle ranges respectively, according to JCPDS: $36-1451$ card, (002) plane is peaked at $34.42^{\circ}$. The $d$-space $(\AA)$ varies from 2.47 to $2.60 \mathrm{~nm}$. A slight angle shift is recorded from $0.410^{-3}$ to $0.1 \mathrm{rad}$ as a result of $\mathrm{Zn}$ amount. Based on structural data extracted from X-ray pattern the grain size $(\mathrm{nm})$ is assessed within the 14.923.8 range according to the (002) direction. Using X-ray pattern, the average lattice parameters a and c are determined and found to be 3.2 and $5.18 \AA$. Doped with tin at several concentration, $\mathrm{ZnO}$ layers show a slight shift to higher Bragg angle for (002) orientation (as indicated by arrow in Fig. 2) whereas the (101) is shifted towards high $2 \theta$ angle, this displacement of peaks is due to cation insertion in host lattice. 


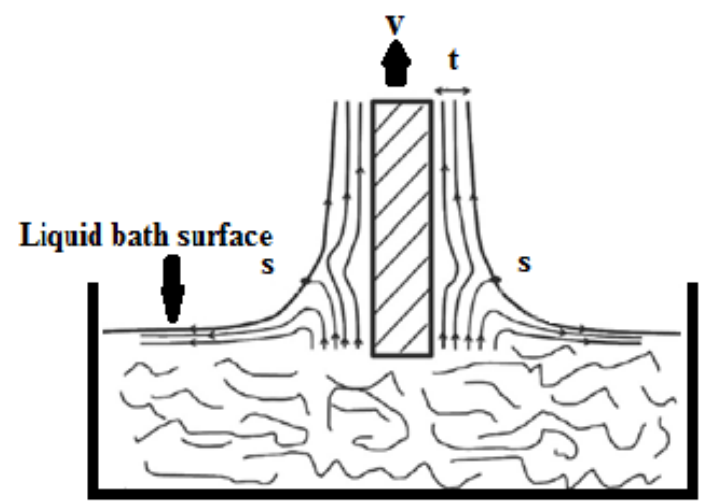

Fig. 1 - Schematic diagram of the dip coating techniques

A (002)-oriented wurtzite hexagonal structure with a lattice parameters of $3.3 \AA$ and $5.2 \AA$ was confirmed by X-ray diffraction. The As-grown layers produced by dip coating route onto glass exhibit a (002) preferential orientation as indicated by arrow in Fig. 2 (I, II and III). The intensity of the (002) peak is improved by high molarity and doping level in particular Al cation. Based on Scherrer formula prior cited [8] the grain size is determined.

The grain size according to (002) orientation varies within 14-28 $\mathrm{nm}$ as a result of $\mathrm{Zn}$ amount in the solution as tabulated below (Table 1). When $\mathrm{ZnO}$ films are doped, it increases till $59 \mathrm{~nm}$ as listed in Tables 1 and 2. Furthermore, the X-ray pattern reveals a plane shift
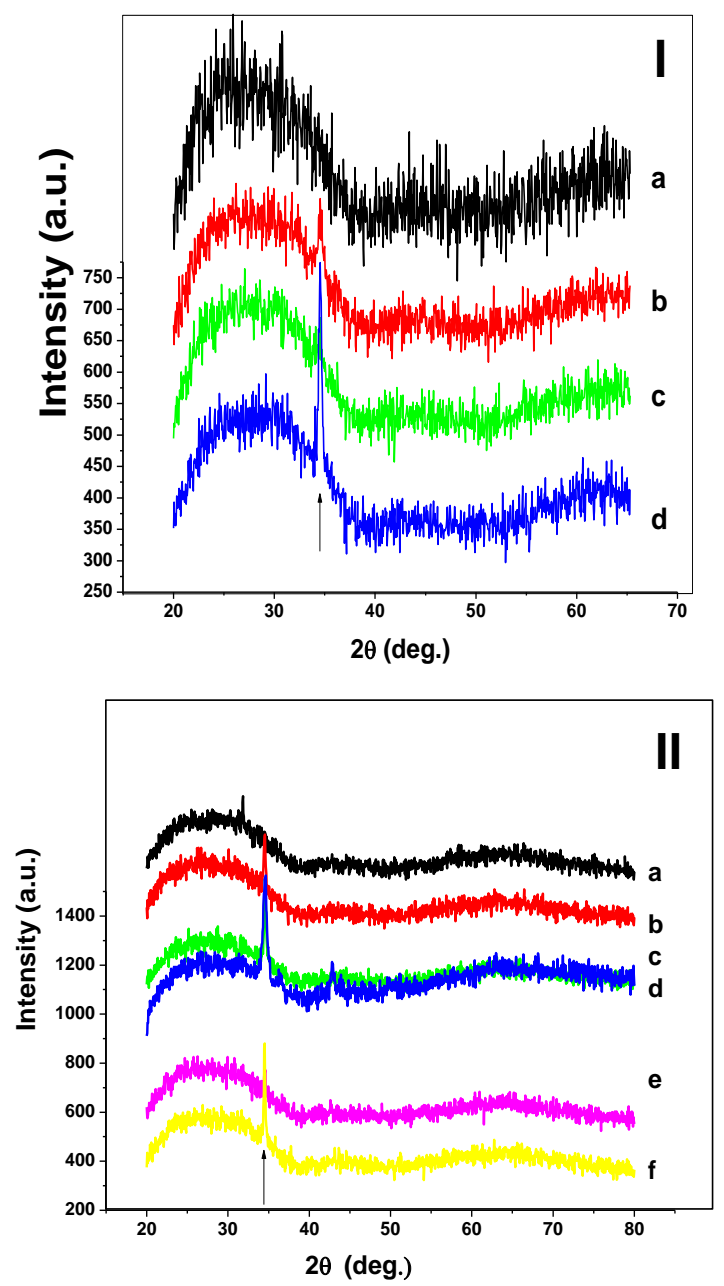

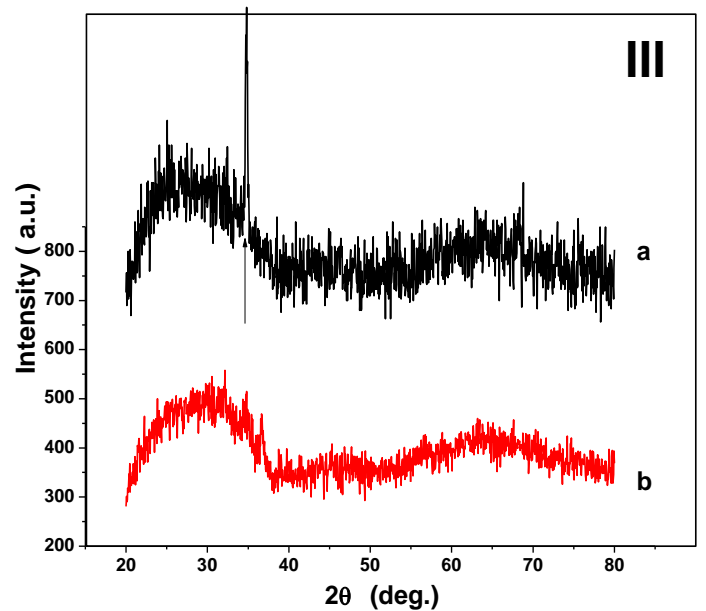

Fig. 2 - XRD spectra for different molarities (I), 2 (a), 3 (b), 5 (c), 10 (d), 15 (e) and 20 (f) \% Sn-doped (II), Al (a) and copper (b) -doped(III) $\mathrm{ZnO}$ films in the $20^{\circ}-80^{\circ}(2 \theta)$ range

towards the high $2 \theta$ Bragg angle as listed in Tables 1-3. A strong orientation of c-axis (002) perpendicular to the substrate is reported by Lee for indium $\mathrm{ZnO}$ thin films [9]. The films show a polycrystalline structure with important (002) direction. Indeed, this reflection peaked at around $34.45^{\circ}$, identifies the wurtzite structure of our as-grown $\mathrm{ZnO}$ and $\mathrm{MZO}$ layers. An increase in $\mathrm{Zn}$ amount and a metallic cation doping change the peak location from $34.4^{\circ}$ to $36.27^{\circ}$ and $36.67^{\circ}$ respectively as listed in Tables 1-3. The lattice parameters a and $\mathrm{c}$ are also influenced by the $\mathrm{Zn}$ amount and metallic ( $\mathrm{Sn}, \mathrm{Al}$ and $\mathrm{Cu}$ ) cation doping and found to be changed around the values of $3.21 \AA$ and $5.18 \AA$ as seen in Tables 2 and 3. It is found in literature that $a$ and $c$ are of $3.24 \AA$ and $5.20 \AA$ for both pure and doped $\mathrm{ZnO}$ [10].

\subsection{Optical Characterization}

The transmittance versus photon wavelength is displayed in the Fig. 3. At the middle of visible range of $550 \mathrm{~nm}$, the obtained values of transmittance are found within $88-91 \%$ range for pure layers and $75-90 \%$ range for $\mathrm{Sn}$ doped $\mathrm{ZnO}$ layers. The transmittance becomes lower (73-80 \%) for the $\mathrm{Al}$ and $\mathrm{Cu}$ doped $\mathrm{ZnO}$ films. Both, $\mathrm{Al}$ and $\mathrm{Fe}$ doping increase the transmittance till $88 \%$ and $83 \%$ for $\mathrm{ZnO}$ films as reported previously $[11,3]$. Sn and $\mathrm{Al}$ ions decrease a little the optical property in visible range of the as-synthesized $\mathrm{ZnO}$ films as mentioned in prior work [12]. The transmittance still roughly constant around a higher value in IR band, similar trends is reported by Lehraki et al. [13]. The optical gap is determined by the variation of the $(\alpha h v)^{2}$ versus photon energy $h v$ (not shown here). This gap goes from 4.35 to $4.42 \mathrm{eV}$ for the pure $\mathrm{ZnO}$ films. Whereas, it varies within the 4.40-4.45 eV energy range for the doped ones. It is mentioned that 3.27 and $3.26 \mathrm{eV}$ are the obtained values of optical band gaps for the pure and $\mathrm{Al}$-doped $\mathrm{ZnO}$ [14]. The highest transmittance at a wavelength of $550 \mathrm{~nm}$ is obtained for the $\mathrm{ZnO}$ layers, which have grown at $400{ }^{\circ} \mathrm{C}$ (> $\left.84 \%\right)$ as reported in recent work [15]. 

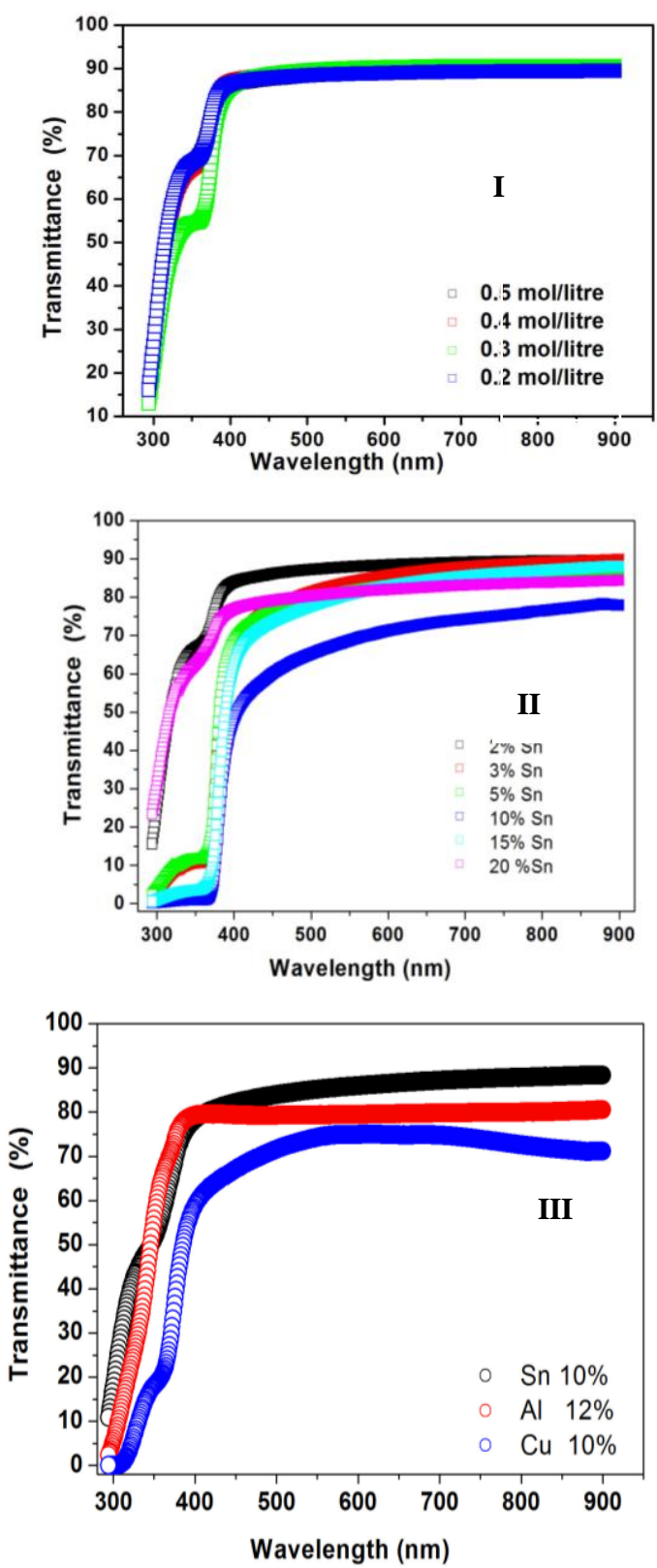

Fig. 3 - Transmittance vs. photon wavelength of undoped at several $\mathrm{Zn}$ proportions (I), Sn- (II), $\mathrm{Al}, \mathrm{Cu}$ (III)-doped $\mathrm{ZnO}$ produced by dip coating route
It is revealed that our pure $\mathrm{ZnO}$ layers exhibit a high transparency $T>85 \%$ ) within the visible range and transmittance reaches a high point of $95 \%$ for the lowest molarity of $0.2 \mathrm{~mol} / \mathrm{liter}$ as shown in Fig. 3.I. Therefore, the transmittance diminishes as molarity increases due to high deposited quantity of $\mathrm{ZnO}$ at high molarity. Over $60 \%$, the transmittance profile indicates a rough square edge in particular for the concentration of $0.2 \mathrm{~mol} / \mathrm{l}$ as sketched in Fig. 3. The 5, 10, 15 and $20 \%$ tin doped $\mathrm{ZnO}$ films are less transparent compared to pure ones. The square edge becomes slight as a result of Sn concentration as shown in Fig.3.II.

\subsection{HMS Measured Values}

At room temperature, the electrical parameters of the samples are measured via Hall effect measurement (HMS), using a magnetic field of $0.58 T$, as shown in Fig. 4 and 5, and are given in Tables 4-5.

A bulk density of holes ( $p$ type) varying from $3.7 \times 10^{12}$ to $13.4 \times 10^{12} \mathrm{~cm}^{-3}$ is confirmed by samples of pure as-grown $\mathrm{ZnO}$ layers when molarity increases from
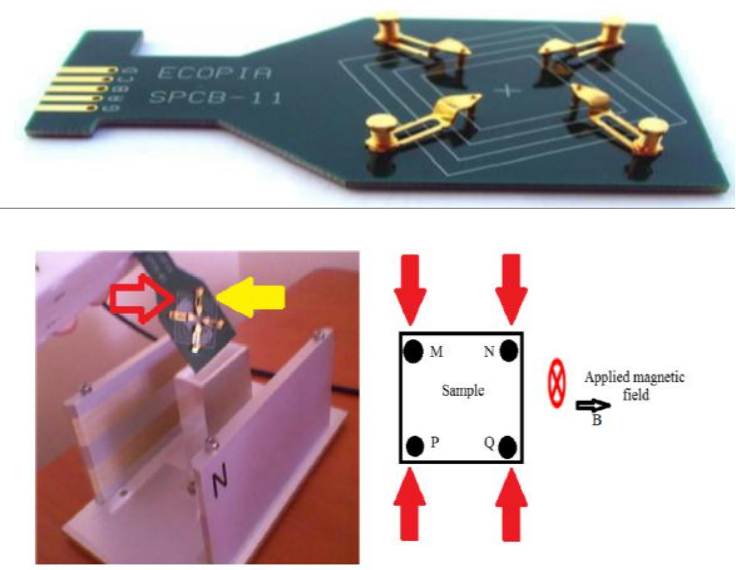

Fig. 4 - Hall measurement apparatus of pure and $\mathrm{M}(\mathrm{Sn}, \mathrm{Al}$, $\mathrm{Cu}$ )-doped $\mathrm{ZnO}$ grown onto glass substrate; the films are kept by four Au probes (red arrow) as signed by yellow arrow (left). As shown at right, the scheme of the samples, the four contacts $\mathrm{M}, \mathrm{N}, \mathrm{P}, \mathrm{Q}$, and the magnetic field is applied perpendicularly to the sample $[4,16]$

Table 1 - The structural parameters of pure $\mathrm{ZnO}$ films at several molarities

\begin{tabular}{|c|c|c|c|c|c|c|c|c|c|}
\hline \multirow{2}{*}{$\begin{array}{l}\text { Pure } \mathrm{ZnO} \text { films } \\
\text { concentration } \\
(\mathrm{mol} / \mathrm{l})\end{array}$} & \multirow{2}{*}{$\begin{array}{l}(h k l) \\
\text { orien- } \\
\text { tation }\end{array}$} & \multirow{2}{*}{$\begin{array}{c}2 \theta \\
\text { (Deg.) }\end{array}$} & \multirow[t]{2}{*}{$d_{h k l}(\AA)$} & \multirow[t]{2}{*}{$\begin{array}{c}\Delta(2 \theta) \\
\left(10^{-3} \mathrm{rad}\right)\end{array}$} & \multirow{2}{*}{$\begin{array}{l}\text { Grains } \\
\text { size } \\
D(\mathrm{~nm})\end{array}$} & \multirow{2}{*}{$\begin{array}{c}\text { Peak Inten- } \\
\text { sity } \\
\text { (arb. u.) }\end{array}$} & \multicolumn{3}{|c|}{$\begin{array}{l}\text { Lattice parameters } \\
(\AA)\end{array}$} \\
\hline & & & & & & & $c$ & $a$ & $c / a$ \\
\hline 0.2 & $(002)$ & 34.41 & 2.60 & 10.14 & 14.95 & 54.0 & \multirow{2}{*}{5.21} & \multirow{2}{*}{3.31} & \multirow{2}{*}{1.5} \\
\hline 0.2 & (101) & 35.72 & 2.52 & 0.43 & & 54.0 & & & \\
\hline 0.3 & (002) & 34.54 & 2.59 & 6.97 & 21.76 & 56.10 & \multirow{2}{*}{5.19} & \multirow{2}{*}{3.29} & \multirow{2}{*}{1.5} \\
\hline 0.3 & $(101)$ & 35.96 & 2.49 & 96.90 & & 44.6 & & & \\
\hline 0.4 & $(002)$ & 34.53 & 2.59 & 6.37 & 23.80 & 52.9 & \multirow{2}{*}{5.19} & \multirow{2}{*}{3.25} & \multirow{2}{*}{1.6} \\
\hline 0.4 & (101) & 36.27 & 2.47 & 0.44 & & 45.8 & & & \\
\hline 0.5 & (002) & 34.54 & 2.5943 & 5.350 & 28.34 & 77.4 & \multirow{2}{*}{5.19} & \multirow{2}{*}{3.25} & \multirow{2}{*}{1.6} \\
\hline 0.5 & (101) & 36.31 & 2.4720 & 33.99 & & 42.4 & & & \\
\hline
\end{tabular}


Table 2 - The structural parameters of Sn doped $\mathrm{ZnO}$ films at several doping levels

\begin{tabular}{|c|c|c|c|c|c|c|c|c|c|}
\hline \multirow{2}{*}{$\begin{array}{l}\text { Sn doped } \mathrm{ZnO} \\
\text { films } \\
\text { concentration } \\
(\mathrm{mol} / \mathrm{l}) \\
\end{array}$} & \multirow{2}{*}{$\begin{array}{c}(h k l) \\
\text { orientation }\end{array}$} & \multirow{2}{*}{$2 \theta$ (Deg.) } & \multirow{2}{*}{$\begin{array}{l}d_{h k l} \\
(\AA)\end{array}$} & \multirow{2}{*}{$\begin{array}{c}\Delta(2 \theta) \\
\left(10^{-3} \mathrm{rad}\right)\end{array}$} & \multirow{2}{*}{$\begin{array}{c}\text { Grains } \\
\text { size } \\
\mathrm{D}(\mathrm{nm})\end{array}$} & \multirow{2}{*}{$\begin{array}{c}\text { Peak } \\
\text { Intensity } \\
\text { (arb.u.) }\end{array}$} & \multicolumn{3}{|c|}{$\begin{array}{l}\text { Lattice parameters } \\
(\AA)\end{array}$} \\
\hline & & & & & & & $c$ & $a$ & $c / a$ \\
\hline \multirow{2}{*}{ Sn $2 \%$} & $(002)$ & 34.54 & 2.59 & 6.96 & 21.78 & 88.0 & \multirow{2}{*}{5.19} & \multirow{2}{*}{3.25} & \multirow{2}{*}{1.6} \\
\hline & (101) & 36.27 & 2.47 & 0.45 & & 43.4 & & & \\
\hline \multirow[t]{2}{*}{ Sn $3 \%$} & $(002)$ & 34.54 & 2.59 & 4.35 & 35.12 & 117.2 & \multirow{2}{*}{5.19} & \multirow{2}{*}{3.24} & \multirow{2}{*}{1.6} \\
\hline & (101) & 36.36 & 2.47 & 6.91 & & 89.8 & & & \\
\hline \multirow[t]{2}{*}{ Sn $5 \%$} & (002) & 34.49 & 2.59 & 4.10 & 37.00 & 82.26 & \multirow{2}{*}{5.19} & \multirow{2}{*}{3.30} & \multirow{2}{*}{1.5} \\
\hline & (101) & 35.79 & 2.51 & 0.97 & & 50.0 & & & \\
\hline \multirow[t]{2}{*}{ Sn $10 \%$} & (002) & 34.57 & 2.59 & 2.56 & 59.16 & 55.20 & \multirow{2}{*}{5.18} & \multirow{2}{*}{3.26} & \multirow{2}{*}{1.6} \\
\hline & (101) & 36.21 & 2.48 & 3.91 & & 42.40 & & & \\
\hline \multirow[t]{2}{*}{ Sn $15 \%$} & (002) & 34.49 & 2.60 & 3.59 & 42.28 & 70.4 & \multirow{2}{*}{5.19} & \multirow{2}{*}{3.25} & \multirow{2}{*}{1.6} \\
\hline & (101) & 36.28 & 2.47 & 0.47 & & 46.0 & & & \\
\hline \multirow[t]{2}{*}{ Sn $20 \%$} & $(002)$ & 34.58 & 2.59 & 3.42 & 44.38 & 72.5 & \multirow{2}{*}{5.18} & \multirow{2}{*}{3.26} & \multirow{2}{*}{1.6} \\
\hline & (101) & 36.19 & 2.48 & 2.92 & & 38.5 & & & \\
\hline
\end{tabular}

Table 3 - The structural parameters of M-doped $\mathrm{ZnO}$ films at several metal amounts

\begin{tabular}{|c|c|c|c|c|c|c|c|c|c|}
\hline \multirow[b]{2}{*}{$\begin{array}{l}\text { M-doped } \mathrm{ZnO} \\
\text { Films (M: Al, Cu) } \\
\text { concentration } \\
(\text { mol/l) }\end{array}$} & \multirow{2}{*}{$\begin{array}{l}(h k l) \\
\text { orien- } \\
\text { tation }\end{array}$} & \multirow[b]{2}{*}{$2 \theta$ (Deg.) } & \multirow[b]{2}{*}{$\begin{array}{l}d_{h k l} \\
(\AA)\end{array}$} & \multirow[b]{2}{*}{$\begin{array}{c}\Delta(2 \theta) \\
\left(10^{-3} \mathrm{rad}\right)\end{array}$} & \multirow[b]{2}{*}{$\begin{array}{l}\text { Grains size } \\
D(\mathrm{~nm})\end{array}$} & \multirow{2}{*}{$\begin{array}{c}\text { Peak Inten- } \\
\text { sity } \\
\text { (arb.u.) }\end{array}$} & \multicolumn{3}{|c|}{$\begin{array}{c}\text { Lattice parameters } \\
(\AA)\end{array}$} \\
\hline & & & & & & & $c$ & $a$ & $c / a$ \\
\hline \multirow[t]{2}{*}{$\mathrm{Al} 12 \%$} & $(002)$ & 34.43 & 2.57 & 4.64 & 32.70 & 91.00 & \multirow[t]{2}{*}{5.15} & \multirow[t]{2}{*}{3.43} & \multirow[t]{2}{*}{1.5} \\
\hline & (101) & 35.78 & 2.51 & 0.42 & & 45.60 & & & \\
\hline \multirow[t]{2}{*}{$\mathrm{Cu} 10 \%$} & (002) & 34.69 & 2.58 & 17.07 & 8.89 & 49.40 & \multirow[t]{2}{*}{5.17} & \multirow[t]{2}{*}{3.21} & \multirow[t]{2}{*}{1.6} \\
\hline & (101) & 36.67 & 2.45 & 12.73 & & 46.90 & & & \\
\hline
\end{tabular}

Table 4 - Electrical parameters of pure dip coated $\mathrm{ZnO}$ films determined by HMS measurement

\begin{tabular}{|c|c|c|c|c|c|}
\hline $\begin{array}{c}\text { Pure ZnO } \\
\mathrm{mol} / \mathrm{l}\end{array}$ & type & $\begin{array}{c}\text { Bulk density } \\
\left(\times 10^{12}\right) \mathrm{cm}^{-3}\end{array}$ & $\begin{array}{c}\text { Mobility } \\
\left(\mathrm{cm}^{2} / \mathrm{Vs}\right)\end{array}$ & $\begin{array}{c}\text { Resistivity } \\
\left(\times 10^{4} \Omega . c m\right)\end{array}$ & $\begin{array}{c}\text { Hall constant } \mathrm{R}_{\mathrm{H}} \\
\left(\times 10^{4} \Omega . c m\right)\end{array}$ \\
\hline 0.2 & $p$ & 7.36 & 15.65 & 5.42 & 84.76 \\
\hline 0.3 & $p$ & 5.91 & 19.23 & 5.49 & 105.7 \\
\hline 0.4 & $p$ & 3.76 & 29.49 & 5.63 & 166.1 \\
\hline 0.5 & $p$ & 13.41 & 8.689 & 5.36 & 46.55 \\
\hline
\end{tabular}

Table 5 - Electrical parameters of Sn-doped ZnO films determined by HMS measurement

\begin{tabular}{|c|c|c|c|c|c|}
\hline $\begin{array}{c}\text { Sn doped ZnO } \\
(\%)\end{array}$ & type & $\begin{array}{c}\text { Bulk density } \\
\left(\times 10^{12}\right) \mathrm{cm}^{-3}\end{array}$ & $\begin{array}{c}\text { Mobility } \\
\left(\mathrm{cm}^{2} / \mathrm{Vs}\right)\end{array}$ & $\begin{array}{c}\text { Resistivity } \\
\left(\times 10^{4} \Omega . c m\right)\end{array}$ & $\begin{array}{c}\text { Hall constant } R_{H} \\
\left(\times 10^{4} \Omega . c m\right)\end{array}$ \\
\hline 2 & $p$ & 1.70 & 57.52 & 6.36 & 365.8 \\
\hline 3 & $n$ & -3.73 & 0.90 & 175.1 & -167.4 \\
\hline 5 & $p$ & 10.73 & 10.63 & 5.48 & 58.19 \\
\hline 10 & $p$ & 29.67 & 3.93 & 5.36 & 21.04 \\
\hline 15 & $p$ & 7.05 & 16.72 & 5.29 & 88.56 \\
\hline 20 & $p$ & 10.81 & 10.85 & 5.32 & 57.74 \\
\hline
\end{tabular}

Table 6 - Electrical parameters of $\mathrm{m}(\mathrm{Al}, \mathrm{Cu})$-doped $\mathrm{ZnO}$ films determined by HMS measurement

\begin{tabular}{|c|c|c|c|c|c|}
\hline $\begin{array}{c}\mathrm{M} \text { doped } \mathrm{ZnO} \\
(\%)\end{array}$ & type & $\begin{array}{c}\text { Bulk density } \\
\left(\times 10^{12}\right) \mathrm{cm}^{-3}\end{array}$ & $\begin{array}{c}\text { Mobility } \\
\left(\mathrm{cm}^{2} / \mathrm{Vs}\right)\end{array}$ & $\begin{array}{c}\text { Resistivity } \\
\left(\times 10^{4} \Omega . c m\right)\end{array}$ & $\begin{array}{c}\text { Hall constant } \mathrm{R}_{\mathrm{H}} \\
\left(\times 10^{4} \Omega . \mathrm{cm}\right)\end{array}$ \\
\hline $\mathrm{Al} 12 \%$ & $p$ & 2.59 & 26.2 & 9.16 & 240.6 \\
\hline $\mathrm{Cu} 10 \%$ & $p$ & 19.32 & 5.73 & 5.63 & 32.3 \\
\hline
\end{tabular}

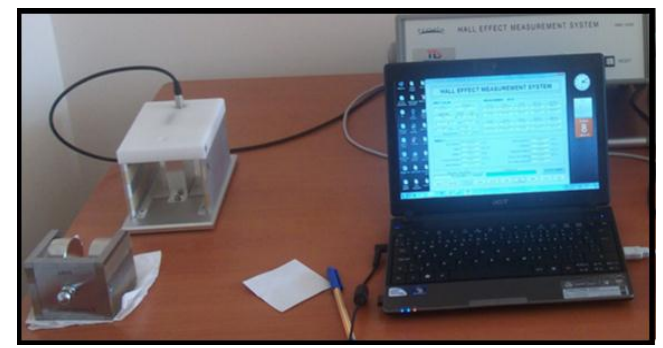

0.2 to $0.5 \mathrm{~mol} /$ litre while resistivity still constant around $5.4 \times 10^{4} \Omega . c m$ as tabulated below (Table 4 ). The Sn- doped samples exhibit a $p$-type except $3 \%$. The mobility is higher and equals to $57.5 \mathrm{~cm}^{2} / \mathrm{Vs}$ for $2 \% \mathrm{Sn}$ doping level and reveals a resistivity of $6.3 \times 10^{4} \Omega . \mathrm{cm}$ as seen in Table 5 . Al doping increases the charge mobility while $\mathrm{Cu}$ cation decreases it as indicated in Table 6.

Fig. 5 - Hall measurement apparatus ecopia HMS-3000 


\section{CONCLUSION}

The pure and metallic doped films of $\mathrm{ZnO}$ are successfully produced by dip coating process. The films are polycrystalline and crystallize according a wurtzite structure with a (002) preferential orientation. The average grain size is about lower and increases with doping level. The as grown $\mathrm{ZnO}$ layers present a high transmittance $>80 \%$ in visible range and a high resistivity $>10^{4} \Omega . c m$ at room temperature.

\section{REFERENCES}

1. C.E. Benouis, M. Benhaliliba, Z. Mouffak, A. Avila-Garcia, A. Tiburcio-Silver, M. Ortega Lopez, R. Romano Trujillo, Y.S. Ocak, J. Alloy. Compd. 603, 213 (2014).

2. Y.S. Ocak, J. Alloy. Compd. 513, 130 (2012).

3. M. Benhaliliba, C.E. Benouis, M.S. Aida, Y.S. Ocak, F. Yakuphanoglu, Int. J. Nanoparticles 6 No 2/3, 239 (2013).

4. M. Benhaliliba, Y.S. Ocak, A. Tab, J. Nano- Electron. Phys. 5 No 3, 03001 (2013).

5. Hui-Huan Guan, Pei-De Han, Yu-Ping Li, Xue Zhang, QiNa Zhang, Li PingWang, Rui-Zhen Zhang, Optik 124, 198 (2013).

6. Sheng Xu, Zhong Lin Wang, Nano Res. 4 No 11, 1013 (2011).

7. L.D. Landau, V.G. Levich, Acta Phys.-Chim. Sin. 17, 42 (1942).

8. Mostefa Benhaliliba, J. New Technol. Mater. 4 No 1, 11 (2014).

9. C. Lee, K. Lim, J. Song, Sol. Energy Mater. Sol. C. 43, 37 (1996).

\section{AKNOWLEDGEMENTS}

This work is included in CNEPRU project $\mathrm{N}^{\circ}$ D01920120039 supported by High Teaching and Scientific Research Ministry www.mesrs.dz and Oran University of Sciences and Technology www.univ-usto.dz. The authors are grateful for the assistance of DUBTAM center Dicle University Ditarbakir Turkey and The Head and staff of the virtual library of SNDL https://www.sndl.cerist.dz.

10. M. Benhaliliba, C.E. Benouis,

M.S. Aida, F. Yakuphanoglu, A. Sanchez Juarez, J. Sol-Gel Sci. Technol. 55, 335 (2010).

11. M. Benhaliliba, C.E. Benouis, M.S. Aida, A. Sanchez Juarez, F. Yakuphanoglu, A. Tiburcio Silver, J. Alloy. Compd. 506, 548 (2010).

12. M. Benhaliliba, C.E. Benouis, A. Tiburcio-Silver, Y.S. Ocak, EPJ Web of Conferences 44, 03003 (2013).

13. N. Lehraki, M.S. Aida, S. Abed, N. Attaf, A. Attaf, M. Poulain, Curr. Appl. Phys. 12, 1283 (2012).

14. Mostefa Benhaliliba, DUFED Dicle. University Journal Institute of Naturel and Applied Science Journal 3 No 1, 79 (2014).

15. M. Benhaliliba, A. Tiburcio-Silver, A. Avila-Garcia, A. Tavira, Y.S. Ocak, M.S. Aida, C.E. Benouis, J. Semiconductors 36 No 8, 083001 (2015).

16. M. Benhaliliba, C.E. Benouis, Y.S. Ocak, F. Yakuphanoglu, J. Nano- Electron. Phys. 4 No 1, 01011 (2012). 